\title{
Riglyne vir die toepassing in die onderrig- leersituasie ten opsigte van tuberkulose
}

M Strydom, M.A. , Skool vir Verpleegkunde, PU vir C.H.O

M Greeff, D. Cur, Skool vir Verpleegkunde PU vir C.H.O.

A Nel, D. Cur

\section{Guidelines for implementation in the education-learning situation regarding tuberculosis}

\section{Opsomming}

Hierdie artikel is " $n$ opvolgartikel van die reeds gepubliseerde artikel "Die belewenis van die pasiënt en die verpleegkundige tydens tuberkulose-onderrig" en fokus op riglyne wat aan die hand van bevindings uit die navorsing geformuleer is. Hierdie riglyne is gestel om die verpleegkundige se kennis en vaardighede ten opsigte van interpersoonlike verhoudinge, vakkennis, taakgeoriënteerde versus pasiëntgeoriënteerde verpleegbenadering, motivering van die verpleegkundige, sosiale ondersteuningstelsels, stimulering van die pasiënt se motivering, herstel van die pasiënt se borsgesentreerdheid en die verantwoordelikheidsaanvaarding vir sy eie gesondheid asook die herstel van die rol van die verpleegkundige, te bevorder.

\section{Abstract}

This article is a follow up article of the previoulsy published article "Die belewenis van die pasiënt en die verpleegkundige tydens tuberkulose-onderrig" and focuses on guidelines formulated on the basis of the research findings. These guidelines have been formulated in order to promote the nurse's knowledge and skills concerning: interpersonal relations, subject knowledge, a task versus patient orientated nursing approach, the motivation of the nurse, social support systems, stimulation of the patient's motivation, recovery from the patient's chest centredness and the acceptance of responsibility for his own health as well as the affirmation of the role of the nurse.

\section{Inleiding}

In 'n vorige gepubliseerde artikel: "Die belewenis van die pasiënt en die verpleegkundige tydens tuberkulose-onderrig" is " $n$ volledige oorsig en verloop van die navorsing gegee. Die tweede doelstelling vir die navorsing was naamlik: om riglyne daar te stel vir die toepassing in die onderrigleersituasie ten opsigte van tuberkulose, wat mag bydra tot die verlaging van die uitvalsyfer onder tuberkulose-pasiënte. Vervolgens spesifieke riglyne wat gestel is aan die hand van die gevolgtrekkings, soos in die bovermelde artikel uiteengesit.

\section{Riglyne soos van toepassing op die verpleegkundige as onderriggewer}

Die temas wat in die belewenisstudie gevind is, het as grondslag gedien vir die sistematisering en uiteensetting van die riglyne wat volg.

\section{Interpersoonlike vaardighede}

\section{Rasionaal:}

Die ontwikkeling van die verpleegkundige se interpersoonlike vaardighede mag daartoe bydra dat ' $n$ terapeutiese interpersoonlike verhouding tussen haar en die pasiënt tot stand kom, haar negatiewe persepsies ten opsigte van onderrig verminder en sy bewus word van die pasiënt se wanpersepsies ten opsigte van tuberkulose.

\section{Riglyne:}

- Oefeninge en strategieë ten opsigte van effektiewe interpersoonlike vaardighede moet in 'n tuberkulose-onderrigprogram ingesluit word.

- As indiensopleiding voorsien word, moet minstens een indiensopleidingsprogram per jaar vaardigheidsoefeninge ter bevordering van effektiewe interpersoonlike verhoudinge insluit, ten einde leer hieromtrent te versterk.

- Verdere riglyne ten opsigte van interpersoonlike vaardighede is soos volg:

\section{1) Selfkennis}

- Die verpleegkundige moet kennis van die "self" bekom, sodat sy in staat kan wees om haarself beter te verstaan, om sodoende die oorsaak van haar gevoelens en reaksies te begryp. - Verdere riglyne ten opsigte van selfkennis is aan die hand van onderafdelings gestel.

\section{- Selfkennis ten opsigte van aspekte van die "self"}

- Deur kennisverwerwing en interpersoonlike vaardigheidsoe- 
feninge mag die verpleegkundige in staat wees om aspekte van die "self" te identifiseer. Dit mag daartoe lei dat sy haarself beter verstaan, mag begryp hoe ander haar beskou en hierdie verworwe kennis dan effektief in die interaksieproses kan toepas. Burnard (1992:6) se benadering ten opsigte van die volgende aspekte van die "self" moet in ' $n$ onderrigprogram ingesluit word:

\section{Die regte "self":}

Die verpleegkundige moet kennis ten opsigte van die innerlike aspekte van die "self", oftewel die "regte" self, verkry. Sy moet vertroud wees met die prosesse van selfbewussyn en selfblootlegging (Burnard, 1992:6; Johnson, 1993:34).

- Wat selfblootlegging betref, moet die verpleegkundige gelei word om meer van haarself aan andere, soos haar vriende of kollegas en later ook pasiënte, bekend te maak. Volgens Burnard (1992:10) mag die verpleegkundige wat die proses van selfblootlegging by andere toepas, ervaar dat hulle op hul beurt ook meer van hulself aan haar bekendmaak - in dié geval dus die tuberkulosepasiënte.

\section{Die geestelike "self":}

- Omdat die geestelike "self", volgens Burnard (1992:16), dit behels waarin die verpleegkundige glo, is dit nodig dat die verpleegkundige haar eie visie en filosofie ten opsigte van gesondheidsonderrig formuleer. Dit mag haar in staat stel om te besef wat sy glo, wat haar persoonlike waardes in die lewe is en hoe sy die tuberkulosepasiënt beskou.

Dit is noodsaaklik dat die verpleegkundige selfkennis ten opsigte van die geestelike "self" bekom, ten einde struikelblokke wat die onderrig-leersituasie kan benadeel, te identifiseer; dus moet die verpleegkundige:

- bewus wees van haar eie waardes, norme en houding teenoor tuberkulosepasiënte;

- bewus wees van haar reaksies wanneer sy in interaksie tree met tuberkulosepasiënte wat nie dieselfde waardes, norme en gelowe as sy het nie;

- die pasiënt vanuit sy oogpunt beskou en nie vanuit die verpleegkundige s' $n$ nie; daarom is dit belangrik dat ' $n$ onderrigprogram 'n basiese kennis ten opsigte van waardes, norme en gelowe insluit. Dit sal die verpleegkundige help om te besef hoe verskillend kan sy en die pasiënt wees.

\section{Die duister/donker aspekte van die "self":}

Die verpleegkundige moet kennis verkry ten opsigte van die duister/donker aspekte van die "self", wat volgens Burnard (1992:19) ook aggressiewe gevoelens en gedagtes wat die verpleegkundige ten opsigte van ander het, behels. Deur middel van die prosesse van selfbewussyn en selfblootlegging moet die verpleegkundige in staat gestel word om haar onverwerkte emosies, soos woede jeens die pasiënt, bekend te maak en dit logies te ontleed, ten einde in staat te wees om beredeneerd en objektief daarmee te handel.

Die konstruktiewe hanteringswyse van woede, soos deur Johnson (1993:273) gestel, moet in die onderrigprogram ingesluit word, naamlik:

- die hoofkomponente en funksies van woede;

- die bevordering van konstruktiewe woede-hantering;

- die ontmoediging van destruktiewe woede-hantering.

Die konsepte selfhandhawende, nie-selfhandhawende en aggressiewe optrede moet in die onderrigprogram ingesluit word (Wilson \& Kneisl, 1988:33; Burnard, 1992:136-139;
Poggenpoel, 1986:4-6).

\section{- Selfkennis ten opsigte van verdedigingsmeganismes}

- Die verpleegkundige moet kennis aangaande verdedigingsmeganismes verwerf om haar in staat te stel om as volwassene-onderriggewer die nadelige uitwerking daarvan in die onderrig-leersituasie te identifiseer en dit te vermy.

- Deur middel van terugvoermeganismes van ander mense kan die verpleegkundige daarvan bewus word wanneer sy van verdedigingsmeganismes gebruik maak (Bradley \& Edinberg, 1990:136).

\section{- Selfkennis ten opsigte van transaksionele analise}

- Transaksionele analise moet in "n onderrigprogram ingesluit word, want die verpleegkundige moet kennis ten opsigte van die verskillende egostate, naamlik volwassene-, ouer- en kind-egostate, soos deur Berne (Harris, 1973:16) gestel, bekom, om haar in staat te stel om:

die egostate ten opsigte van kommunikasie in haarself en andere te identifiseer;

interaksies vanuit haar volwassene-egostaat aan te knoop, wanneer dit die toepaslikste metode is;

haar of die pasiënt se emosies, wat vanuit die kind-egostaat ten opsigte van kommunikasie mag ontspring, te identifiseer en reg te stel.

- Die verpleegkundige moet dus weet wat elke egostaat in kommunikasie behels en deur middel van vaardigheidsoefeninge in staat wees om vanuit 'n volwassene-egostaat ten opsigte van kommunikasie die onderrig-leersituasie te hanteer.

\section{2) Terapeutiese verhouding en kommunikasievaardighede}

- Die verpleegkundige moet oor die nodige kennis en vaardighede ten opsigte van effektiewe kommunikasie beskik, want volgens Greeff (1990:10) is effektiewe kommunikasievaardighede nodig ten einde ' $n$ terapeutiese interpersoonlike verhouding tot stand te bring.

- Dit is belangrik dat die verpleegkundige daarna streef om eerlikheid en openheid by die pasiënt aan te moedig, deur vir hom die geleentheid hiertoe tydens die interaksieproses te skep. 'n Leeromgewing met fisiese gemak, wedersydse respek, vertroue en behulpsaamheid, vryheid van spraak en aanvaarding van verskille, soos deur Knowles (1986:7) verduidelik, kan bydra tot 'n oop en eerlike verhouding.

- Die verpleegkundige moet haar kennis uitbrei ten opsigte van die volgende vaardighede en houdings, omdat dit belangrik is in die daarstelling van ' $n$ terapeutiese verhouding (Greeff, 1990:13; Poggenpoel, 1984:16-17; Stanhope \& Lancaster, 1988:191).

\section{- Empatie}

Kongruensie tussen verbale en nie-verbale kommunikasie Onvoorwaardelike aanvaarding

- Respek

Warmte

Egtheid

Betroubaarheid

Opregte belangstelling. 


\section{Vakkennis ten opsiate van tuberkulose}

\section{Rasionaal:}

Die verbetering van die verpleegkundige se vakkennis ten opsigte van tuberkulose mag daartoe lei dat die verpleegkundige ' $n$ breër perspektief as net medikasievoorsiening aan en die voorkoming van nadelige gewoontes van die tuberkulosepasiënt, het.

\section{Riglyne:}

- Die volgende is die basiese aspekte wat in "n onderrigprogram ingesluit moet word (Strebel \& Seager; 1991:58-85):

- Epidemiologie

- Etiologie

Diagnose

Behandeling

Voorkoming van tuberkulose.

- Die verpleegkundige se kennis ten opsigte die volgende aspekte van tuberkulosebeheer en

-behandeling moet uitgebrei word:

- Die verband tussen sosio-ekonomiese aspekte en tuberkulose (Metcalf, 1991:26).

Kulturele aspekte wat volgens Gumede (1990:39) tuberkulosebeheer en -behandeling mag beïnvloed.

Sosiale stigma ten opsigte van tuberkulosepasiënte (De Villiers, 1991:70).

Newe-effekte van medikasie (Enarson et al. 1994:17-18). Emosionele en aanpassingsprobleme van die pasiënt (Burton, 1977:268).

\section{Vakkennis ten opsigte van onderrig}

\section{Rasionaal:}

Deurdat die verpleegkundige vakkennis ten opsigte van onderrig verwerf en dit in die onderrig-leersituasie toepas, mag dit daartoe bydra dat die verpleegkundige die pasiënt binne sy sosio-kulturele verband leer ken, toepaslike en doeltreffende onderrig aan hom bied wat die moontlikheid skep dat leer by die pasiënt mag plaasvind.

\section{Riglyne:}

Riglyne word aan die hand van onderafdelings gestel.

\section{1) Kennis van die leerpsigologie}

- 'n Onderrigprogram moet die volgende ten opsigte van die leerpsigologie insluit (Fraser et al.. 1990:69):

- Hoe vind leer plaas.

- Watter faktore mag moontlik bydra tot betekenisvolle en optimale leer.

- Die verpleegkundige moet oor die nodige kennis van faktore wat ' $n$ invloed op leer by die pasiënt mag uitoefen, beskik, ten einde elke pasiënt as ' $n$ individu te beraam en onderrigstrategieë volgens dié bevindinge aan te pas. Faktore soos deur Van Hoozer et al. (1987:29-41) uiteengesit, moet in die onderrigprogram opgeneem word, naamlik die invloed van: oorerflikheid en die omgewing;

groei, ontwikkeling en gereedheid tot leer;

fisiese faktore, naamlik biologiese, psigologiese, omgewings- en sosiokulturele faktore;

- leerstyl, modaliteitsterkte, kognitiewe styl en leervoorkeure.

\section{2) Kennis van onderrig-leerbeginsels}

- Die verpleegkundige moet kennis van die onderrig-leerbeginsels, soos deur Fraser et al. (1990:55-79) verduidelik, verwerf. Minstens die volgende onderrig-leerbeginsels moet in " $\mathrm{n}$ onderrigprogram ingesluit word.

- Motivering

Individualisering

- Geheelsiening

Evaluering

Beplanning

- Sosialisering

Doelgerigtheid

Moedertaalonderrig

Aktiwiteitsbeginsel

- Die verpleegkundige moet ook " $n$ basiese kennis van onderrigstrategieë, -metodes en -media verwerf. Die volgende beginsels moet deur die verpleegkundige hieromtrent in aanmerking geneem word.

Kulturele aspekte van die leerder.

Bevordering van ' $n$ multimedia-onderrigbenadering (Fraser et al.. 1990:64).

- Onderrigstrategieë, -metodes en -media moet die aktiewe deelname van die pasiënt bevorder.

\section{3) Kennis van die onderrigproses}

- Vir die daarstelling van doeltreffende onderrig moet die verpleegkundige oor die nodige kennis van die fases van onderrigproses beskik, soos deur Coutts en Hardy (1985:132195) gestel, naamlik beraming, beplanning, implementering en evaluering.

- 'n Volledige beraming van die pasiënt vind in die beramingsfase plaas, en alleen die addisionele data wat die verpleegkundige ten opsigte die tuberkulosepasiënt moet bekom na aanleiding van die resultate van hierdie navorsing, is aan die hand van die kategorieë en subkategorieë van die Verplegingsteorie vir Mensheelheid (ORU, 1990:136-142; RAU, 1991:7) weergegee.

\section{Interne omgewing}

Die interne omgewing bestaan uit die subkategorieë: liggaamlik, psigies en geestelik, waarvolgens die volgende riglyne gestel is.

\section{Liggaamlik}

Die verpleegkundige moet ' $n$ volledige liggaamlike beraming van die pasiënt uitvoer en aan die volgende aspekte aandag skenk.

Die mate waarin die pasiënt pyn ervaar, wat leer mag belemmer (Coutts \& Hardy, 1985:107-108).

Newe-effekte, indien die pasiënt reeds onder behandeling is.

\section{Psigies: intellektueel}

Die pasiënt se gereedheid ten opsigte van leer moet deur die verpleegkundige bepaal word (Roberts, 1978:142).

Die verpleegkundige moet ook ' $\mathrm{n}$ bepaling van die pasiënt se vermoë om te leer uitvoer (Coutts \& Hardy, 1985:66). 
Deur middel van analise moet die verpleegkundige die pasiënt se vorige ondervinding en kennis ten opsigte van tuberkulose vasstel, waarvolgens sy dan haar onderrig alanpas. Foutiewe inligting en wanpersepsies ten opsigte van tuberkulose waaroor die pasiënt beskik, moet reeds by aanvang van onderrig, deur middel van tweerigtingkommunikasie, deur die verpleegkundige vasgestel word.

Die verpleegkundige moet ook beraam of die pasiënt se taal van kommunikasie 'n probleem kan skep (Coutts \& Hardy, 1985:63). Hierdeur kan sy bepaal wanneer sy van 'n tolk gebruik moet maak.

\section{Psigies: emosioneel}

Die emosionele belewenisse van die pasiënt moet deur die verpleegkundige beraam word, en waar negatiewe emosies, soos vrees, teenwoordig is, moet die oorsprong vasgestel en verwyder word. Volgens Coutts en Hardy (1985:64) kan negatiewe emosies verhoed dat leer plaasvind.

\section{Psigies: wil}

Die verpleegkundige moet bepaal in watter mate die pasiënt ten opsigte van leer gemotiveer is (Van Hoozer et al.. 1987:295). In dié verband mag die pasiënt se begeerte na gesondheid 'n aanduiding van motivering wees.

\section{Geestelik}

Die pasiënt se waardes en gelowe moet deur die verpleegkundige vasgestel word (Van Hoozer et al.. 1987:235). Dit mag die pasiënt se verbondenheid tot sy behandeling beinvloed.

\section{Eksterne omgewing}

Die eksterne omgewing bestaan uit die subkategorieë: fisies, sosiaal en geestelik.

\section{Fisies}

Indien die pasiënt reeds onder tuberkulosebehandeling is, moet die verpleegkundige beraam of die pasiënt weet wat die korrekte dosis is, hoe lank hy sy medisyne moet neem, asook wat die gevolge is as hy sy behandeling voor die minimumbehandelingstydperk staak, soos deur Packard (1991:53) verduidelik.

Die verpleegkundige moet vasstel of die pasiënt die verband tussen sosio-ekonomiese toestande en tuberkulose begryp, soos deur Metcalf (1991:26) uiteengesit.

\section{Sosiaal}

Die gesin, as sosiale ondersteuning, moet deur die verpleegkundige evalueer word, asook die verskillende hulpbronne wat in die gemeenskap is.

Hierby ingesluit is ook ' $\mathrm{n}$ kulturele beraming van die gesin en die gemeenskap, soos deur Van Hoozer et al. (1987:235) aangetoon, asook die mate waarin die pasiënt die kulturele sieninge handhaaf.

' $n$ Bepaling van die pasiënt se vorige ondervindige met gesondheidsdienste moet gedoen word, want volgens Coutts en Hardy (1985:95) mag dit die pasiënt se motivering ten opsigte van leer beïnvloed.

Die verpleegkundige moet ook vasstel hoe die pasiënt haar as hulpbron sien. Dit bied haar die geleentheid om die persepsie dat sy net daar is met die oog op medikasievoorsiening, reg te stel.

\section{Geestelik}

Die geestelike ondersteuning wat die pasiënt geniet, byvoorbeeld kerkverband en beskikbare geestelike amptenare, moet deur die verpleegkundige vasgestel word om as hulpbronne benut te word.

\section{Kennis van taakqeoriënteerde versus pasiëntqeoriënteerde verpleeqbenadering}

\section{Rasionaal:}

Kennis van 'n taakgeoriënteerde en pasiëntgeoriënteerde verpleegbenadering mag daartoe bydra dat die verpleegkundige meer van 'n pasiëntgeoriënteerde benadering in onderrig gebruik maak.

\section{Riglyne:}

- 'n Uiteensetting van taakgeoriënteerde en pasiëntgeoriënteerde benadering (Pearson, 1991:194-198) moet in die onderrigprogram ingesluit word, ten einde die verpleegkundige in staat te stel om die nodige kennis ten opsigte van:

'n taakgeoriënteerde benadering te verwerf en sodoende hierdie benadering en sy nadele in die onderrig-leersituasie te identifiseer en daarvan af te sien;

- 'n pasiëntgeoriënteerde benadering te bekom, wat haar in staat mag stel om hierdie kennis in die onderrig-leersituasie toe te pas ten einde die interaksieproses te bevorder.

\section{Motivering van die verpleegkundiqe}

\section{Rasionaal:}

Deur die geleentheid vir die verpleegkundige te skep om meer gemotiveerd op te tree, mag dit daartoe bydra dat die onderrigleersituasie ook vir haar ' $n$ positiewe belewenis mag inhou.

\section{Riglyne:}

Riglyne is aan die hand van onderafdelings gestel.

\section{1) Kennisverryking}

- Deurdat aspekte, soos interpersoonlike vaardighede, vakkennis ten opsigte van tuberkulose en onderrig, asook taakgeoriënteerde versus pasiëntgeoriënteerde verpleegbenadering in ' $n$ onderrigprogram ingesluit word, mag dit daartoe bydra dat die verpleegkundige se kennis vermeerder en haar belangstelling ten opsigte van tuberkulose toeneem. In dié verband toon Fraser et al. (1990:57) aan dat motivering ontwikkel met die toename van belangstelling in "n taak wat aangeleer word. Indien die toepassing van hierdie verworwe kennis deur die verpleegkundige daartoe bydra dat die pasiënt hom meer tot sy behandeling verbind, mag dit aanleiding daartoe gee dat die verpleegkundige meer persoonlike prestasie beleef. 


\section{2) Organisasie-ondersteuningstelsel}

- Dit is belangrik dat daar ' $n$ ondersteuningstelsel vir die verpleegkundige in die lewe geroep word, wat nie net aandag aan haar vaardigheid en kennis skenk nie, maar ook aan haar as totale mens. In hierdie verband wys Wright (1991:111) daarop dat terapeutiese verpleging nie alleen die gewilligheid en verbondenheid van die verpleegkundige tot verdere ontwikkeling behels nie, maar ook die volkome ondersteuning van die organisasie insluit.

Die verpleegkundige moet ondersteuning van haar organisasie ontvang deur die daarstelling van persoonlike en professionele ontwikkelingsgeleenthede, wat indiensopleiding- en onderrig-programme vir die hantering van tuberkulosepasiënte in die onderrig-leersituasie behels.

- Tuberkulose-opleidingsprogramme moet spesifiek deur onderriggewers wat kundiges op dié gebied is, aangebied word.

- Deurlopende opleiding en ondersteuning moet aan die verpleegkundige in haar daaglikse hantering van tuberkulose gebied word. Die tuberkulose-onderriggewers kan in dié verband hierdie ondersteuning en opleiding bied, en hulle vervul dan die rol van ' $n$ mentor vir die verpleegkundige.

\section{3) Groepsondersteuningstelsel}

- Die verpleegkundiges moet onderlinge groepe vorm, waar ' $n$ forum geskep kan word om hulle in staat te stel om mekaar te ondersteun asook om hul kennis en vaardighede ten opsigte van die daarstelling van effektiewe interpersoonlike verhoudinge te beoefen.

- Die verpleegkundiges moet mekaar ook tydens die aanbieding van onderrig evalueer, ten einde mekaar te help ten opsigte van doeltreffende onderrig.

\section{Die gesin as sosiale ondersteuninastelsel}

\section{Rasionaal:}

Deurdat die verpleegkundige die gesin by die onderrigleersituasie betrek, mag dit daartoe bydra dat die pasiënt se verbondenheid tot sy behandeling verbeter.

\section{Riglyne:}

Die verpleegkundige moet kennis dra van die invloed wat die gesin op die verbondenheid van die pasiënt tot sy behandeling het.

- Verder is dit nodig dat sy haar eie taakgeoriënteerde verpleegbenadering, soos deur Alfano (Pearson, 1991:195) gestel, identifiseer, naamlik dat die gesin as ' $n$ inmenging in haar werk beskou word. Om dus weg te breek van hierdie benadering moet die verpleegkundige die gesin pertinent uitnooi en betrek by onderrigaangeleenthede; sodoende mag die verbondenheid van die pasiënt tot sy behandeling verhoog en is die verpleegkundige ook in staat om die waarde wat die gesin as ondersteuningstelsel en hulpbron vir haarself inhou, te ontdek.

\section{Tuberkulosepasiënte as qroepsondersteuninqstelsel}

\section{Rasionaal:}

Deurdat die verpleegkundige tuberkulosepasiënte as groepsondersteuning in die onderrig-leersituasie benut, mag dit daartoe bydra dat die pasiënt 'n aktiewe rol in die onderrigproses vertolk.

\section{Riglyne:}

- Die verpleegkundige moet die pasiënt aanvanklik self onderrig, waarna die pasiënt dan, met begeleiding van die verpleegkundige, andere kan onderrig. Dit is dus moontlik om die tuberkulosepasiënt reeds van die staanspoor af as ' $n$ rolmodel en onderriggewer vir nuwe tuberkulosepasiënte en die gemeenskap op te lei, en terselfdertyd mag die pasiënt se selfwaarde hierdeur ook verhoog word. In dié verband toon Roberts (1978:138) aan dat die pasiënt wat ervaar hy beteken iets, ook ervaar dat hy in beheer is.

- Verder moet die verpleegkundige die geleentheid vir die pasiënt skep om sy ervaringe ten opsigte van tuberkulose met ander tuberkulosepasiënte te deel, wat die ontstaan van 'n onderlinge ondersteuningstelsel bevorder, wat wederkerige hulpverlening, soos deur Knowles (1980:58) gestel, insluit.

\section{Riglyne wat in ag geneem moet word ten opsigte van die pasiënt as leerder}

Riglyne in dié verband is soos volg.

\section{Stimulering van die pasiënt se motiverina en herstel van sy verantwoordelikheidsaanvaarding}

\section{Rasionaal:}

Deurdat die verpleegkundige die pasiënt se motivering stimuleer, mag dit daartoe bydra dat die pasiënt die verantwoordelikheid vir sy eie gesondheid aanvaar.

\section{Riglyne:}

- Die toepassing van kennis en vaardighede ten opsigte van die onderrig-leerbeginsels en die volwassene-egostaat ten opsigte van kommunikasie in die onderrig-leersituasie deur die verpleegkundige mag daartoe bydra dat die pasiënt se motivering gestimuleer en sy verantwoordelikheidsaanvaarding vir sy eie gesondheid bevorder word.

- Die verpleegkundige moet die noodsaaklikheid van die pasiënt se aktiewe deelname aan die onderrigproses begryp en bevorder. Die aktiewe, wederkerige deelname van die pasiënt aan die interaksieproses kan volgens McMahon (1991:8) daartoe bydra dat die pasiënt homself as " $n$ vennoot saam met die verpleegkundige in sy eie gesondheidsorg beskou. Dit mag tot verdere stimulering van die pasiënt se motivering lei.

- Verder moet die benadering van Roberts (1978:143) in die onderrigprogram ingesluit word. Volgens hierdie benadering kan faktore en omstandighede daartoe lei dat die pasiënt magteloos/hulpeloos is. Hierdie "mag" of "beheer" wat die pasiënt verloor het, kan herwin word indien die verpleegkundige die pasiënt se psigologiese, fisiologiese en omgewingsbeheer herstel en ook wanneer die pasiënt se kennis ten opsigte 
van sy siekte vermeerder.

Die volgende riglyne bepaal dus die herstel van die tuberkulosepasiënt se psigologiese, fisiologiese, omgewings- asook bykomend sy geestelike beheer. Die versterking van leer en kennis by die pasiënt sal ook aandag geniet.

\section{1) Herstel van die psigologiese beheer van die pasiënt}

Riglyne word aan die hand van onderafdelings gestel.

\section{- Herkenning van die pasiënt se doel}

- Die verpleegkundige moet die pasiënt se begeerte na gesondheid wat hy uitspreek, as mikpunt/doel vir hom stel om te bereik. In dié verband wys Roberts (1978:183) daarop dat die pasiënt se doel die hoofdeterminant ten opsigte van motivering is. Wanneer dié doel vir die pasiënt as mikpunt gestel word, sal daar, volgens haar, ' $n$ afname in die voorkoms van regressiewe gedrag plaasvind, want die hoop om sy doel te bereik word dan die pasiënt se interne motivering.

\section{- Die verloop van die onderrigproses, insluitend kommunikasie}

- Om "n "gejaagde"-atmosfeer tydens onderrig uit te skakel, wat " $n$ nadelige invloed op die pasiënt se psigologiese beheer het, moet die volgende riglyne deur die verpleegkundige toegepas word:

Geen pasiënt moet onderrig word terwyl die verpleegkundige in ' $n$ staande posisie verkeer nie. " $n$ Persepsie van haastigheid mag so voorkom word

Die verpleegkundige moet haar onverdeelde aandag aan die pasiënt wy en is byvoorbeeld nie besig om aantekeninge te maak wanneer die pasiënt praat nie.

- ' $n$ Terapeutiese verhouding moet deur die verpleegkundige tussen haar en die pasiënt tot stand gebring word, omdat dit ook mag bydra tot die herstel van die pasiënt se psigologiese beheer. Die volgende riglyne word in hierdie verband gestel:

Deur die daarstelling van 'n effektiewe interpersoonlike verhouding mag die verpleegkundige in staat gestel word om die pasiënt as geloofwaardig te aanvaar, terwyl hy sy gevoelens en idees teenoor haar mag lug en sy dit respekteer, terwyl sy ook ruimte vir kulturele verskille hierdeur laat.

Instede daarvan om vir die pasiënt te vertel wat hy mag en nie mag doen nie, kan die verpleegkundige hom eerder tot aktiewe deelname aanmoedig, terwyl sy die geleentheid skep dat hy sy belewenisse aan haar bekend maak. Volgens Roberts (1978:138) beleef die pasiënt dat hy psigologiese beheer verkry wanneer hy die geleentheid gegun word om sy gevoel van frustrasie, woede, vyandigheid, angs of vrees bekend te maak. Nie alleen kan die pasiënt ervaar dat hy in beheer is nie, maar dit mag ook daartoe bydra dat die pasiënt verantwoordelikheid vir sy eie gesondheid aanvaar.

Die verpleegkundige moet luistervaardighede toepas. Deur aktief te luister, beteken volgens Roberts (1978:138) dat die pasiënt toestemming het om te praat, sonder dat die verpleegkundige hom in die rede val.

\section{2) Herstel van die fisiologiese beheer van die pasiënt}

- Die verpleegkundige moet die pasiënt onderrig ten opsigte van sy behandeling, insluitend die behandelingstydperk, neweeffekte van die medikasie, die fisiese vordering wat hy telkens bereik en wat hy op verskeie tydstipte in sy behandelingstydperk kan verwag (Enarson et al..1994:17-18). Dit mag daartoe bydra dat die pasiënt ook op fisiologiese vlak in beheer van sy gesondheidsorg geplaas word.

\section{3) Herstel van die beheer van die omgewing van die pasiënt}

- Waar dit in die vermoë van die verpleegkundige is, soos in ' $n$ vaste kliniek, moet sy ' $n$ aangename fisiese omgewing skep. In " $n$ mobiele kliniek sal dit moeiliker gaan, maar indien dit nie moontlik is nie, moet die verpleegkundige, waar moontlik, die pasiënt in sy eie huis hanteer, sodat die omgewing vir hom bekend is, wat daartoe mag bydra dat sy angs verminder.

- Die verpleegkundige moet die stoele van haar en die pasiënt skuins teenoor mekaar en naby mekaar plaas, met geen lessenaar tussenin nie, om die kommunikasieproses te bevorder. Verder mag dit moontlik daartoe bydra dat die stigma ten opsigte van tuberkulose nie deur die verpleegkundige aangehelp word nie en die pasiënt ook nie die verpleegkundige as verhewe beleef nie.

- Sover dit moontlik in die vermoë van die verpleegkundige is, moet sy ' $n$ aangename temperatuur, goeie ventilasie en beligting in die omgewing skep, wat ' $n$ ontspanne atmosfeer mag bevorder.

- Die verpleegkundige moet muurversierings aanbring wat van so " $n$ aard is dat dit tot ' $n$ aangename, rustige atmosfeer mag bydra. In dié verband wys Van der Merwe (1991:23) daarop dat kleure soos geel, groen en blou tot die skep van 'n rustige atmosfeer bydra.

- Die pasiënt het die reg tot privaatheid; daarom moet die verpleegkundige die deur van die vertrek waar die onderrig plaasvind, toetrek, en ander personeel moet ingelig word dat geen persoon die vertrek mag binnekom nie. Dit mag ook daartoe bydra dat die verpleegkundige haar onverdeelde aandag aan die pasiënt skenk.

\section{4) Herstel van die geestelike beheer van die pasiënt}

- Deurdat die verpleegkundige "n effektiewe interpersoonlike verhouding met die pasiënt handhaaf, mag dit bydra tot die herstel van die pasiënt se geestelike beheer van sy gesondheid, omdat ' $n$ terapeutiese verhouding tot stand mag kom en die pasiënt die geleentheid gebied word om sy gevoelens te lug.

\section{5) Versterking van leer en kennis}

- Die verpleegkundige moet, in samewerking met die pasiënt, 'n leerkontrak tussen haar en die pasiënt opstel (Van Hoozer et al.. 1987:246). Dit mag bydra tot die bevordering van die pasiënt se betrokkenheid by die onderrig-leersituasie, asook van sy verantwoordelikheidsaanvaarding vir sy eie gesondheid.

- Die verpleegkundige moet die pasiënt so onderrig dat hy " $n$ geheelsiening van tuberkulose het. Dit behels dus dat hy die oorsake, risiko-faktore, gevolge en voorkoming van tuberkulose in volle perspektief kan sien, asook die onderlinge verband tussen sosio-ekonomiese toestande en tuberkulose. Korrekte medikasiegebruik is dus net 'n gedeelte van tuberkuloseonderrig. Die verpleegkundige moet gevolglik komplekse denke, eerder as lineêre denke soos deur Bradley en Edinberg (1990:201-202) verduidelik, by die pasiënt 
aanmoedig.

- Die pasiënt moet deur die verpleegkundige by die formulering van die leerdoelwitte betrek word.

- Die verpleegkundige moet toesien dat die pasiënt gedeeltelike verantwoordelikheid vir die beplanning en implementering van die onderrig-leersituasie aanvaar. In dié verband moet die verpleegkundige die verskillende onderrigmetodes en -media wat beskikbaar is, aan die pasiënt bekendstel, en hom dan by die gesamentlike besluitneming en geskiktheid daarvan betrek.

- Die pasiënt se resultate van sy diagnostiese ondersoeke, soos $\mathrm{x}$-strale en sputummonsters, moet deur die verpleegkundige aan hom getoon word en op lekevlak verduidelik word. Terselfdertyd kan hierdie diagnostiese ondersoekresultate ook as onderrigmedia beskou word en as sodanig deur die verpleegkundige benut word.

- Die pasiënt kan ook vertrou word om sy x-strale in sy besit te bewaar. Dit mag die gevoel dat hy in beheer van die situasie en sy gesondheid is, versterk.

- Die verpleegkundige moet tweerigtingkommunikasie aanmoedig, deur onder andere van oopeindevraagstelling gebruik te maak. Dit mag daartoe bydra dat die verpleegkundige haar vergewis van die pasiënt se persepsies ten opsigte van tuberkulose, die teenwoordigheid van kommunikasiestruikelblokke soos konkrete taalgebruik, asook watter begrippe meer verduideliking verg. Terselfdertyd mag die pasiënt se kennis ten opsigte van tuberkulose ook verbeter.

\section{Herstel van die pasiënt se borsuesentreerdheid}

\section{Rasionaal:}

Deurdat die verpleegkundige die pasiënt begelei met die doel om sy borsgesentreerdheid te verminder, mag dit daartoe bydra dat die pasiënt ' $n$ breër siening van tuberkulose ontwikkel, terwyl sy emosionele ervaringe van vrees ook in die proses verminder.

\section{Riglyne:}

- Die verpleegkundige moet die pasiënt die geleentheid bied waar hy sy emosionele belewenisse aan haar kan meedeel, sodat dit konstruktief hanteer word. Die geleentheid mag moontlik geskep word deur die toepassing van 'n volwassene-egostaatbenadering ten opsigte van kommunikasie (Harris, 1973:16) en effektiewe interpersoonlike vaardighede. - Deurdat die verpleegkundige die denkbenaderings, soos deur Bradley en Edinberg (1990:201-202) gestel, naamlik komplekse eerder as lineêre denke, ten opsigte van tuberkulose as onderwerp moet bevorder, mag dit daartoe bydra dat die pasiënt ' $n$ breër siening van sy siektetoestand as net sy bors het.

\section{Die herstel van die rol van die verpleegkundige}

\section{Rasionaal:}

Indien die verpleegkundige se rol in die onderrig-leersituasie herstel word, mag dit daartoe bydra dat sy en die pasiënt haar rol as ondersteunende hulpbron identifiseer en die pasiënt van haar ondersteunende hulp gebruik maak.

\section{Riglyne:}

- Die verpleegkundige moet kennis dra van die huidige tendens waar sy deur die pasiënt net as hulpbron in die voorsiening van medikasie gesien word.

- Om die pasiënt in staat te stel om 'n ruimer opvatting van haar te hê, moet dic verpleegkundige kennis ten opsigte van haar verskillende rolle verwerf en weet hoe en wanneer om elke rol toe te pas, naamlik die rol van advokaat, konsultant, koördineerder, berader, onderriggewer, evalueerder, beplanner, voorsiener, navorser en spesialis.

- Die verpleegkundige moet die pasiënt ten opsigte van die gesondheidsdiens oriënteer, asook wat haar aandeel in die pasiënt se behandeling gaan wees en op watter wyses sy hom van hulp kan wees (Van Hoozer et al.. 1987:237). Dit mag die persepsie dat die verpleegkundige net die pasiënt kan help vir sover dit die voorsiening van medikasie betref, teëwerk.

- Die verpleegkundige moet haar beywer vir die totstandkoming van ' $n$ terapeutiese verhouding tussen haar en die pasiënt. Nie alleen mag dit daartoe bydra dat die pasiënt se siening van die verpleegkundige verruim nie, maar ook dat die verpleegkundige haarself as ondersteunende hulpbron aan die pasiënt sal openbaar.

\section{Samevatting}

Uit die navorsing wat gehandel het oor: "Die belewenis van die pasiënt en die verpleegkundige tydens tuberkuloseonderrig" is riglyne gestel vir die toepassing in die onderrigleersituasie van tuberkulose, wat moontlik tot die verlaging van die uitvalsyfer onder tuberkulosepasiënte mag bydra 
BRADLEY JC \& EDINBERG MA 1990: Communication in the nursing context. 3rd ed. Norwalk : Appleton \& Lange.

BURNARD P 1992: Know yourself: self-awareness activities for nurses. London : Scutari Press.

BURTON G 1977: Interpersonal relations: a guide for nurses. 4th ed. New York: Springer.

COUTTS LC \& HARDY LK 1985: Teaching for health: the nurse as health educator. Edinhurgh : Churchill Livingstone.

DE VILLIERS S 1991: Tuberculosis in anthropological perspective. South African journal of ethology, 14(3):6972. Mar.

\section{ENARSON DA; RIEDER HL \& ARNADOTTIR T 1994:} Tuberculosis guide for lower income countries. 3rd ed. Paris: International Union Against Tuberculosis and Lung Diseases.

FRASER WJ; LOUBSER CP \& VAN ROOY MP 1990: Didaktick vir die voorgraadse student. Durban: Butterworths.

GREEFF M 1990: Building blocks. Nursing RSA, 5(7):1013 , Jul.

GUMEDE MV 1990: Traditional healers: a medical practitioner's perspective. Braamfontein : Skotaville Publishers.

HARRIS TA 1973: I'm ok - you're ok. London : Pan Books.

JOHNSON DW 1993: Reaching out: interpersonal effectiveness and self-actualization. 5th ed. London : Allyn and Bacon.

KNOWIES MS 1980: The modern practice of adult education: from pedagogy to androgogy. Cambridge, N.Y. : The Adult Education Company.

McMAHON R 1991: Therapeutic nursing: theory, issues and practice. (In McMahon, R. \& Pearson, A., eds. Nursing as therapy. London : Chapman \& Hall. p. 1-25.)

METCALF C 1991: A history of tuberculosis. (In Coovadia, H.M. \& Benatar, S.R., eds. A century of tuberculosis: South African perspectives. Cape Town : Oxford University Press. p. 1-31.)

ORU (ORAI. ROBERTS UNIVERSITY ANNA VAUGHN SCHOOL. OF NURSING) 1990: Self study report, submitted to the council of baccalaureate and higher degree programs, national league for nursing. Narrative by criteria, $1: 136-142$, Aug.

PACKARD RM 1991: Holding back the tide: TB control efforts in South Africa. (In Coovadia. H.M. \& Benatar, S.R., eds. A century of tuberculosis: South African perspectives. Cape Town : Oxford University Press. p. 42-57.)

PEARSON A 1991: Taking up the callenge: the future for therapeutic nursing. (In McMahon, R. \& Pearson, A., eds. Nursing as therapy. London : Chapman \& Hall. p. 192210.)

POGGENPOEL M 1984: Psigiatriese verpleegvaardighede in ander verpleegdimensies. Curationis, 7(4):13-18;29, Des.

POGGENPOEL M 1986: Psigiatriese verpleegkunde metodes en vaardighede. Kaapstad : JUTA.

RAU (RANDSE AFRIKAANSE UNIVERSITEIT) 1991: Verplegingsteorie vir Mensheelheid. Johannesburg.

ROBERTS SL 1978: Behavioral concepts and nursing throughout the life span. Englewood Cliffs : Prentice-Hall.

STANHOPE M \& LANCASTER J 1988: Community health nursing: process and practice for promoting health. St. Louis : C.V. Mosby.

STREBEL, PM \& SEAGER JR 1991: Epidemiology of tuberculosis in South Africa. (In Coovadia, H.M. \& Benatar, S.R., eds. A century of tuberculosis: South African perspectives. Cape Town : Oxford University Press. p.58-90.)

VAN DER MERWE N 1991: Listening: a skill for everyone. Cape Town: Arrow.

VAN HOOZER HL; BRATTON BD; OSTMOE PM; WEINHOLTZ D; CRAFT MJ; GJERDE CI \& ALBANESE MA 1987: The teaching process: theory and practice in nursing. Sydncy : Prentice-Hall.

WILSON HS \& KNEISL CR 1988: Psychiatric nursing. 3rd ed. Redwood Dity, Calif. : Addison-Wesley.

WRIGHT S 1991: Facilitating therapeutic nursing and independent practice. (In McMahon, R. \& Pearson, A., eds. Nursing as therapy. London: Chapman \& Hall. p. 102-118.) 